Ewelina Marcińczyk
University of Białystok
Poland
ORCID ID: https://orcid.org/0000-0002-2529-3837

Bartosz Borowik

University of Białystok

Poland

bart.borowik@gmail.com

ORCID ID: https://orcid.org/0000-0002-2886-0155

\title{
PRACTICAL APPLICATION AND CRIMINAL ASPECTS OF CRYPTOCURRENCIES
}

\begin{abstract}
The paper discusses cryptocurrencies both in terms of their applicability to everyday financial transactions as well as in terms of criminogenic factors. The Authors will present practical ways to settle in virtual currency, institutions in which bitcoin payments can be made and the possibility of converting them into traditional currencies. Also factors conducive to combine cryptocurrencies with the criminal world, such as the anonymity of both the Internet and cryptocurrencies will be analysed. In addition, the paper presents the real impact of cryptocurrencies on the increase in crime worldwide, both related to financing of terrorism and in connection with taxation of income. The data and conclusions contained in this study are a contribution to the discussion on the sense of investing in cryptocurrencies, and above all on the opportunities and threats that entail the widespread introduction of this method of payment.
\end{abstract}

Keywords: cryptocurrency, criminal, bitcoin

\section{Introduction}

In this paper the Authors are going to present transactions which can be paid for with Bitcoin and ways in which cryptocurrencies could take a more materialized form. The Authors are also going to discuss the negative side of cryptocurrencies, which is their involvement in crime. It is very likely that in the next 10 years cryptocurrencies will become a commonly used currency. The purpose of this work is to show the advantages and disadvantages of using cryptocurrencies. The Authors will apply the dogmatic and legal method to analyse the status of the cryptocurrencies in the Polish law.

\section{Definition of Bitcoin}

Nowadays it is really hard to find a person interested in finances who has not heard of cryptocurrencies. At the same time, not many people pay attention to how important cryptology is in terms of the development of law on new technologies. Kryptós logos in Latin which means 'hidden world' is an integral part of functioning in the cyberspace [Prabucki 2016, p. 106]. Recently, virtual currencies have been one of the most discussed topics. There are many reasons for that, e.g. they are a relatively new phenomenon developing dynamically, but primarily because there is so much more to discover about them, so it is not surprising that they get so much interest. For some people cryptocurrencies are a way of living and they make a lot of money on them.

However, for people who are not really interested in how the mechanisms of cryptocurrencies work everything about it sounds like nonsense, and the Internet does not help either. It provides a definition of cryptocurrency as "a digital asset designed to work as a medium of exchange that uses strong cryptography to secure financial 
transactions, control the creation of additional units, and verify the transfer of assets" [Schueffe 2017, p. 8]. This definition is not as clear as it looks, and it requires going deeper into the topic to understand its concepts. If we were about to dig deeper into the world of cryptocurrencies through constructive articles, and if we were going to analyse 'webinar' from Youtube on this topic, it seems that cryptocurrencies, particularly Bitcoin, is something that functions not only in the IT world, but in the real world as well. Cryptocurrencies can be acquired in two ways. You can buy them or 'dig' them. If someone has got cryptocurrencies in their virtual wallet ${ }^{1}$ [Piech 2016, p.11], they can be used in a number of ways. One of them is using them to pay for transactions online. There are maps of shops, found on websites such as bitcoin.pl or coinmap. org, which include the names of shops that accept Bitcoin payments. It is important to mention that the number of these shops is still growing.

\section{Bitcoin as a Form of Payment}

Online shops are not everything. In some stationary shops or restaurants, it is possible to pay with the virtual currency - currently, there are around 100 of these places in Poland [Map 2018, online]. The procedure of such a transaction is not complicated. It involves using a BITPAY ${ }^{2}$ application by the seller and buyer which can be installed on either a tablet or a smartphone. The seller has to put the price in the application and all it takes is to scan the QR code with a smartphone which is synchronised with the client's wallet or scan two devices together - it depends on the application. However, there is a lot of information on the Internet about how shops only want to freely advertise themselves, but in fact they do not take cryptocurrency payments, so it is important to confirm it before buying anything or ordering from a restaurant. Payments with cryptocurrency are not only used by small companies or institutions but also massive companies such as Dell or Microsoft. Bitcoins can also be used to top-up your phone in Polish mobile operators: Heyah and T-Mobile. Large corporations are aware that for increasingly demanding and looking for interesting alternatives consumers, cryptocurrency payment can

\footnotetext{
1 Virtual Wallet - a collection of private keys or software for managing cryptocurrencies and for carrying out transactions in the Bitcoin network. It can be a mobile application, device, Internet service or even a paper wallet containing a given value of cryptocurrencies.

BitPay is cryptocurrency payment method. It is a modern platform that allows you to accept Bitcoin and other cryptocurrencies as a payment method. In order to make a payment on the spot BitBayPay Terminal app is required, which is available on mobile devices.
}

influence their decision on purchasing products from this particular company. In addition, as mentioned earlier, it can be an excellent, and the most important, free advertising for such a company. Between 2015 and 2016 you could pay with Bitcoin for a flight ticket in the Polish airlines LOT [Sołoma, Spychalski 2017, p. 230]. Previously only 2 lines in the world decided to take this step - Air Baltic airlines in 2014 and at the beginning of 2017 Japanese airlines Peach Aviation. Currently the Polish airlines has resigned from this type of payment. We hope that this is only temporary and that this large company will give cryptocurrency another chance. Especially since the experts of the cryptocurrency market say the big boom is only about to happen when less specialised investors join the market. Interestingly, you can pay with Bitcoin for services in Medicover, the biggest private Polish health centre in Warsaw. There is also a Bitcoin Taxi in the capital city [Kryża 2017, online]. Cryptocurrencies are a global currency so it is worth mentioning that you can purchase apartments in Dubai with Bitcoin. Luxury apartments can be purchased for a price of only 14.83 Bitcoin (according to the data for 10.40 p.m. on 4 March, this converts to 170 000 US dollars). In terms of the real estate, The Collective, a developer from London, allows the possibility to pay the rent with Bitcoin. On the other hand, the Polish website kantorbitcoin.pl proposes payment service for standard utility bills via Bitcoin. With this type of institutions, Bitcoin payment is possible in any industry, and the inconveniences with currency conversion is on the company, which provides the exchange services. On the other hand, the company that proposes currency conversion bears the risk of the exchange-rate fluctuation. However, with the skilful observation of cryptocurrency market it can enlarge its income through a series of transactions on virtual currencies. In 2010, 2 pizzas were bought for 10,000 BTC - it was the first, historic transaction with cryptocurrency. According to the exchange rate on $4^{\text {th }}$ March, 22.40 BTC gives an amount of over three hundred and eighty-nine million Zloty. In relation to food it is worth saying that since June 2017 on a very well-known website in Poland pyszne.pl you can pay for orders with Bitcoin. When you click on the "order and pay", you will be automatically redirected to the BitPay Payment Agent page, where you will be given access to your wallet, from which you need to send a payment request. In order to convert the Bitcoin course, the current price quoted on Bitpay is applied. No additional administrative fee is charged for the transaction. With BTC you can pay in nearly 5 thousand restaurants in the country. It is a really impressive scale. In many cities, ATMs adapted for bitcoin operations are also being built. Those devices allow selling Bitcoin, Litecoin and 
Ethereum. People that already have the cryptocurrency can convert it to Polish Zloty, and in the case of a device with "both sides" they can also purchase the cryptocurrency. This completely changes the virtual currency image, which can be converted into real money. Bitcoin ATMs have started to emerge in Poland since 2015 and currently they can be found only in several cities, including Krakow, Bydgoszcz and Gdansk. It is therefore difficult to believe those who claim that cryptocurrencies have a small chance for greater development. The acquisition of goods with money earned by the computer system alone is a very tempting option, especially since they do not require the effort of own work, but only adequate technical preparation and high financial input at the beginning.

\section{Anonymity of Cryptocurrencies}

Unfortunately, the virtual currency is used not only in a positive way. Bitcoin offers so many possibilities including anonymity that it is sometimes called "the currency of free people". It sounds a bit over the top if you consider the daily economic crisis and the uncertainty of banking transactions. Cryptocurrency not having the authority of central entity and having a system of effective money flow control has become the primary money used by criminals around the world. Every city on earth has its dark face. Dangerous neighbourhoods and places where you can easily find criminals. Also, the Internet which is called the "global village" has its dark side. Another face of the Internet is usually called the $\mathrm{TOR}^{3}$ or Freenet ${ }^{4}$ network. Access to these networks requires a special software and appropriate configuration of the computer so the anonymity on the dark side of the Internet is at a very high level.

The dark web is used by criminals, law enforcement agencies, agencies, spies, special agents, journalists, gun dealers

\footnotetext{
The TOR (The Onion Router) network was created by specialists from the American Navy. Its purpose was to allow secret government agents to view network resources fully anonymously and without leaving the slightest trace of their presence. In contrast to commonly known networks, the data is coded and then sent by a huge number of consecutive servers, thus preventing the person logging in on its level from being tracked down. In other words, before the data comes from point A to point B, they are constantly encrypted and go to the recipient not directly, but by a circuit. Information is decoded at point B only after passing through several other paths.

4 Freenet is a free software that allows you to anonymously share files, view and publish "freesites" (websites available only through Freenet) and chat on forums, without fear of censorship. Freenet is decentralized, making it less susceptible to attack, and if it is used in darknet mode, where users only connect with friends, it is very difficult to detect.
}

and human traffickers, or even professional paid assassins. Everyone in this group benefits from the non-cash transfer service offered by Bitcoin. In combination with the anonymising network connection TOR and guaranteed anonymity of Bitcoin transaction, cryptocurrencies are the main currency of the dark web. In the underground Internet there are cryptocurrencies "laundries". Thus, criminals have a ready-made platform to make business based on trading illegal goods as well as "laundering" illegal Bitcoins. Bitcoins obtained in a way which is against the law or earned through the execution of an illegal service can be withdrawn from the ATM in an acceptable currency for the offender and then can be used as legal means of payment.

The dark side of the Internet is also a place for many online shops offering products of illegal origin, as well as illegal goods such as drugs, chemicals or weapon. You could buy a rifle with Bitcoin that will be send to the buyer to the given address or parcel locker. The anonymity of cryptocurrencies increases the access for illegal goods to ordinary people, often tempted by the simplicity of getting something forbidden and become criminals in the light of the law. Not to mention the criminal groups who have the ability to sell drugs, weapon or people anonymously, they constantly expand their illegal markets. The hidden network is almost as old as the whole Internet. However, illegal Internet transactions do not always remain anonymous. A transfer leaving a bank will always has its record on the corresponding statement. The offender using legal money has never been anonymous. Only the development of cryptocurrencies and their wide availability allows for a greater anonymity in the Internet. As we have previously mentioned, in many Polish cities, including Bialystok, there is a possibility of illegal and anonymous exchange of Polish Zloty to the appropriate cryptocurrencies at special ATMs. Nothing stands in the way for the holder of the cryptocurrency to be a minor or even a child who is interested in the dark side of the Internet, which can eventually contribute to committing a crime or become a criminal.

\section{Impact of the Bitcoin on Criminality}

Thanks to the anonymity of cryptocurrency, Bitcoin has become the means of supporting terrorism in the world. Also in Poland cryptocurrencies have already contributed to the emergence of companies issuing invoices for non-site transactions, at the same time trading the cost of doing business which translates into a series of economic crimes. Yet another crime category in relation to virtual currency trading is money laundering. In order to reduce 
the scale of this phenomenon, the Act of $16^{\text {th }}$ November 2000 on prevention of money laundering practices and terrorist financing was introduced based on Article 8, paragraph 3-3b. It is clear from the content that the institution which makes the transaction, whose circumstances indicate that it may be related to money laundering or terrorism financing, is required to register such transaction irrespective of its nature and value. However, there is no direct reflection in the case of cryptocurrencies. Professional bodies involved in creating digital currency exchange platforms are not in the circle of entities obliged to register undoubted transactions [Czaplicki 2017, p. 4445]. Cryptocurrencies are commonly used in illegal activity. Approximately one-quarter of all users (25\%) and close to one-half of bitcoin transactions (44\%) are associated with illegal activity. Furthermore, approximately one-fifth $(20 \%)$ of the total dollar value of transactions and approximately one-half of bitcoin holdings (51\%) through time are associated with illegal activity. [Foley, Karlsen, Putninš 2018, online] The impact of Bitcoin and its social reception depends only on its users, it can make life easier through instant transfers, alternative ways to earn money and also to enlarge the grey spending zone, illegal goods transactions and the development of cybercrime in a broad sense. Bitcoin and other cryptocurrencies do not influence directly the rise of crime in the world. Alternative and anonymous forms of payment, however, remove one of the many barriers between a rightful citizen and an offender. On the other hand, the widespread ability of Bitcoin payment is not such a distant future as it might seem. In addition, it is a very attractive solution. The only, but the most significant factor that can inhibit the development of this payment method are the fluctuations of the cryptocurrency course. Through its instability it can deter entrepreneurs and investors to implement this method in their structures. The way for sudden decreases in values may be the design used for example in Dubai which was previously mentioned. There, the risk of changing the Bitcoin exchange rate was transferred onto the buyer through fixing the price in US dollars, and the conversion to Bitcoin occurred after the rate at the time of making the contract.

\section{Conclusions}

Undoubtedly, the issue of cryptocurrencies for many years will be in the area of interest to lawyers in many ways, e.g. economic, criminal, and fiscal. It is worth to follow the latest changes in the national and European legislation and it is worth to invest in cryptocurrency to give yourself a chance to face the opportunities given to us by the modern world. Universality in bitcoin payments is a near future. The presented article shows only selected companies accepting virtual currencies, their number is constantly growing. Thirst for virtual currencies continues despite significant exchange rate fluctuations and will continue for many years. It is difficult to find clear evidence that cryptocurrencies affect crime growth but the anonymity of currency transfers is a factor that encourages illegal behaviour

\section{Bibliography}

Czaplicki P. (2017), Wybrane przestępstwa gospodarcze zwiqzane $z$ obrotem waluta Bitcoin $w$ prawie polskim, Unii Europejskiej oraz Stanów Zjednoczonych, „Studenckie Zeszyty Naukowe" Vol. XX, no. 32.

Foley S., Karlsen J.R., Putniņš T.J. (2018), Sex, drugs, and bitcoin: How much illegal activity is financed through? [online], www.cashessentials.org/app/uploads/2018/07/ foley_karlsen_talis_sex_drugs_and_bitcoin.pdf.

Kryptowaluta coraz bardziej popularna. Gdzie zapłacisz bitcoinem w Polsce [online], www.businessinsider.com.pl/finanse/kryptowaluty/ bitcoin-gdzie-mozna-zaplacic-kryptowaluta/yw7hrfz.

Kryża P. (2018), Co można kupić za bitcoina? [online], www. climb2change.pl/co-mozna-kupic-za-bitcoina.

Map of Bitcoin accepting venues [online], www.coinmap. org.

Piech K. (red.) (2016), Leksykon pojęć na temat technologii blockchain i kryptowalut. Strumień „Blockchain i Kryptowaluty” programu „Od papierowej do cyfrowej Polski”.

Prabucki R. (2016), Kryptologia a prawo - wybrane zagadnienia: idea kryptowaluty i jej wpływu na ewolucję oszustw $w$ Internecie „Przegląd Nauk Stosowanych”.

Schueffe, P. (2017), Zwięzłe kompendium Fintecha, Szkoła Zarządzania, Fryburg, Szwajcaria.

Sołoma A., Spychalski K. (2017), Zastosowanie bitcoinów we wspótczesnej gospodarce elektronicznej, „Kolegium Analiz Ekonomicznych" no. 45.

What is Cryptocurrency: Everything You Need to Know, Ultimate Guide [online], www.blockgeeks.com/guides/ what-is-cryptocurrency.

\section{Legal acts}

Ustawa z dnia 16 listopada 2000 r. o przeciwdziałaniu praniu pieniędzy oraz finansowaniu terroryzmu (Journal of Laws 2000 No. 116 item 1216 later amended). 